\title{
Municipal identity. A multilevel analysis of the determinants of individual attachment to municipalities
}

\author{
Marc Bühlmann
}

\begin{abstract}
The article focuses on the determinants of municipal identity, itself considered to be an important prerequisite of civic and political engagement. The determinants of attachment to the municipality of residence are derived from four different theoretical approaches. They are tested by means of multi-level analyses to look into the question of the effect of individual and contextual characteristics on the development of municipal identity. The analysis of Swiss municipalities shows that municipal identity is a multi-dimensional concept, consisting of affective attachment and formal as well as informal integration. On the whole, individual as well as aggregate spatial mobility have rather a negative impact on individual municipal identity. By contrast, individual interests in terms of home ownership and parenthood have rather a positive influence on the development of local attachment. The analyses further point to the importance of including contextual conditions: the development of an individual's municipal identity depends on the size of the respective municipality as well as its socio-economic, cultural, institutional and macro-economic attributes.
\end{abstract}

Keywords: Community attachment $\cdot$ Local context $\cdot$ Multi-level analysis $\cdot$ Swiss municipalities

\section{Kommunale identität. Eine mehrebenenanalyse der determinanten individueller verbundenheit mit der gemeinde}

Zusammenfassung: Im Zentrum dieses Beitrages steht die Erklärung kommunaler Identität, die als wichtige Voraussetzung zivilgesellschaftlichen und politischen Engagements betrachtet wird. Mit Hilfe von Determinanten aus vier unterschiedlichen Ansätzen zur Erklärung der Verbundenheit mit der Wohngemeinde wird auf der Basis von Mehrebenenanalysen der Frage nachgegangen, welche individuellen und kontextuellen Eigenschaften die Entwicklung kommunaler Iden-

\author{
Published online: 14.02 .2012 \\ (C) VS Verlag für Sozialwissenschaften 2011
}

I would like to thank Lisa Müller, Lisa Schädel, Fritz Sager and the two anonymous reviewers for their helpful comments. Parts of this research were conducted within the project 'Democracy Barometer' that is part of the NCCR Democracy, the National Center of Competence in Research 'Challenges to Democracy in the 21st Century' sponsored by the Swiss National Science Foundation at the Centre for Democracy Research in Aarau (ZDA).

Dr. M. Bühlmann $(\bowtie)$

Institut für Politikwissenschaft, Universität Bern,

Lerchenweg 36, 3000 Bern 9, Schweiz

e-mail: marc.buehlmann@ipw.unibe.ch 
tität beeinflussen. Die Analyse von Schweizer Gemeinden zeigt, dass es sich bei der kommunalen Identität um ein mehrdimensionales Konzept handelt, das aus affektiver Verbundenheit sowie informeller und formeller Einbindung besteht. Individuelle und aggregierte räumliche Mobilität wirken insgesamt eher negativ auf die individuelle kommunale Identität. Eigeninteressen in Form von Hausbesitz und Elternschaft zeigen hingegen einen eher positiven Einfluss auf die Entwicklung lokaler Verbundenheit. Schließlich vermögen die Analysen die Bedeutung des Einbezugs kontextueller Rahmenbedingungen deutlich zu machen: Die Generierung kommunaler Identität ist abhängig von der Größe einer Gemeinde sowie von sozioökonomischen, kulturellen, institutionellen und makroökonomischen Kontextmerkmalen.

Schlüsselwörter: Kommunale Identität · Lokale Kontexteinflüsse · Mehrebenenanalyse · Gemeinden der Schweiz

\section{Introduction}

The topic of this essay is municipal identity. By municipal identity, we mean an individual's attachment to his or her municipality of residence and his or her social integration into the municipal environment (Bolan 1997; Gerson et al. 1977; Kasarda and Janowitz 1974; Ringel and Finkelstein 1991; Sampson 1988; Woolever 1992). Municipal identity is considered an important prerequisite for individual civic and political engagement in the municipal context. Only those people who feel attached to their municipality and identify with their place of residence develop curiosity for social and political events (Bolan 1997, p. 226; Lipset et al. 1954). Identity therefore becomes the minimal prerequisite for a functioning democracy, especially on the municipal level, and stands at the beginning of the development from a simple resident to a democratic citizen (Barber 1994, p. 152). Curiosity leads to political interest and someone who is interested will develop political knowledge and competence, become politically engaged and develop trust in the political system (Ladner and Bühlmann 2007, pp. 117-118). In short, only individuals who develop a municipal identity will become political citizens - at least at local level (Lowndes 1995, pp. 161-162; Marshall 1964). In the context of the discussion on declining civic and political engagement (Putnam 2000), it is therefore crucial to know the determinants of municipal identity as the basis of (local) political action. In this essay, we will therefore examine the prerequisites and determining factors of municipal identity.

Studies on municipal identity have a long tradition in the social sciences (Sampson 1988, p. 766). 'Attachment' has been the subject of numerous empirical studies since the early works of Toennies ([1887] 1991) or Wirth (1938). In the literature, we find a number of different schools and approaches concerned with the explanation of municipal identity. Research into 'community' underlines the importance of spatial mobility for the intensity of attachment to a municipality. According to this approach, residential mobility (change of place of residence) and circular mobility (commuters' movement between their place of residence and their place of work) exert a negative influence on the attachment to one's community (Kasarda and Janowitz 1974, pp. 330-331; Sampson 1988). The 'declineof-community' approach emphasizes the size of municipalities. Increasing urbanization is believed to weaken the identification with the municipality and the informal social networking of an individual (Fischer et al. 1977, pp. 101-103; Nie et al. 1969, p. 819; Verba and Nie 1972). Within the approach of 'community of limited liability', social and 
economic interests play a paramount role for an individual's attachment to a municipality. Only when an individual has to defend an economic and social self-interest does he or she develop municipal identity (Gerson et al. 1977; Greer 1962, pp. 113-116).

More recent studies from the social capital research have shown that social integration not only depends on individual attitudes and resources, but also on the environment that sets the 'frame of action' for an individual, and which can vary sociodemographically, culturally or institutionally (Bühlmann and Freitag 2004, p. 344; Schofer and FourcadeGourinchas 2001, p. 807).

The present contribution tests these four approaches empirically. The focus of the analysis is on individuals from different Swiss municipalities. In addition to individual determinants, the impact of contextual factors is also considered. The study aims at contributing to the closure of at least three research gaps:

First, previous studies on municipal identity have almost exclusively focused on individual determinants. This is owing to the use of individual opinion surveys (Coleman 1986, pp. 1314-1315; Sampson 1988, pp. 766-767). The social context is not considered at all. In the present contribution, municipal identity is considered to be dependent on the context of the respective municipality as well. Based on a dataset that combines the characteristics of 56 Swiss municipalities with responses of 30 individuals from each municipality, the effects of contextual and individual determinants are modelled and simultaneously examined with the help of multi-level analyses.

Second, it is commonly accepted that municipal identity is a multi-dimensional concept (Gerson et al. 1977, p. 144; Taylor et al. 1984). However, attachment is usually measured using only one single indicator. The present contribution considers the multi-dimensional structure of communal identity by using different dimensions of municipal identity.

Third, even though studies on 'attachment' have a long tradition, there are no systematic studies on municipal identity in Switzerland. ${ }^{1}$ Swiss municipalities lend themselves very well as objects for examination, precisely because Switzerland - as a highly decentralized country - grants large autonomy to its sub-units. As a consequence, municipalities possess very high significance in political and social life (Ladner and Bühlmann 2007, pp. 3 ff.). Additionally, the 'laboratory of Switzerland' offers ideal conditions for simultaneous analyses of individual and contextual determinants (Freitag 2005).

This article proceeds as follows: in the next section, the concept of 'municipal identity' will be discussed and its multi-dimensionality will be underpinned empirically. The approaches used in the explanation of individual municipal identity are the subject of the third section. The fourth section is dedicated to the description of data and method, while the fifth section contains the empirical analyses. Concluding remarks are presented in the last section.

1 Exceptions are Bassand et al. (2001), Joye et al. (1995), Kübler (2005) and Meyer et al. (1992), who all only look at a small number of few cities. systematic and generalizable comparisons between randomly selected municipalities are not made. 


\section{Municipal identity as a research topic}

What explains one's attachment to a municipality? How do individual and contextual characteristics influence the shape of municipal identity? In the literature, different concepts for measuring municipal identity are used. It becomes clear that attachment to a municipality is a construct of different individual attitudes. Municipal identity is therefore considered a multi-dimensional concept, being composed of different sources (Gerson et al. 1977; Kasarda and Janowitz 1974; Taylor et al. 1984). Differentiation is made between attitudes towards municipalities (affective and attitudinal attachment) and individuals' behavioral patterns (social integration and behavioral attachment) (cf. Bolan 1997, p. 226):

1. Attitudinal attachment to a municipality is considered an important pillar of municipal identity. Bolan (1997, p. 226) makes a distinction between "an individual's emotional attachment to a community" ('sentiment') and "an individual's satisfaction with the residential environment" ('evaluation'). Individuals feeling attached to their municipality tend to connect their own fate much more closely to the happenings in their municipality, "resulting in a closer linkage of personal concerns to politics" (Strate et al. 1989, p. 452).

2. Municipal identity is also a result of behavioural attachment in the form of social integration. Depending on the degree of formalization, social integration can be divided into two sub-dimensions (Stinner et al. 1990, p. 502). Informal integration corresponds to non-formal interpersonal contacts, e.g. between neighbors (Coleman 1991, p. 413) whereas formal social integration is based on individual engagement in institutions and organizations (e.g. going to church, being a member of an association) (Gabriel et al. 2002, p. 104-107.).

Previous studies on municipal identity have neglected the posited multi-dimensionality. Usually, the phenomenon is measured using a single variable. For the present study, a number of variables taken from a population survey (cf. Sect. 4) are at disposal to capture and determine the concept of municipal identity in all its facets.

In line with existing literature, attitudinal attachment is measured using questions concerning feelings of attachment to one's municipality and neighbourhood. Furthermore, satisfaction with life in one's municipality is asked for. Social integration is measured using variables on membership of associations, church attendance and interaction within the neighbourhood (neighborly help and discussions). ${ }^{2}$

A factor analysis ${ }^{3}$ confirms the assumption that municipal identity is a multidimensional concept (see Fig. 1).

2 The operationalising of all variables can be found in the appendix (Table 4).

3 The aim of the factor analysis is to detect mutual independent variables (Backhaus et al. 2000, p. 253). Variables are aggregated to factors based upon the fundamental theorem that each observation can be described as a linear combination of (hypothetical) factors. The connections of the different variables (as measured by correlations) are reproduced in a multi-dimensional space. The resulting factors can be interpreted as resultants of different vectors. 


\begin{tabular}{|c|c|c|c|}
\hline & $\begin{array}{c}1 \\
\text { Affective } \\
\text { attachment }\end{array}$ & $\begin{array}{c}\text { Factor } \\
2 \\
\text { Informal } \\
\text { integration }\end{array}$ & $\begin{array}{c}3 \\
\text { Formal } \\
\text { integration }\end{array}$ \\
\hline Sentiment of attachment to municipality & .805 & .175 & .211 \\
\hline Sentiment of attachment to neighbourhood & .608 & .505 & .199 \\
\hline Satisfaction with life in the municipality & .741 & -.080 & -.113 \\
\hline Frequency of neighbourly help & .080 & .858 & .034 \\
\hline Frequency of discussion with neighbors & .045 & .856 & .036 \\
\hline Membership of associations & -.055 & .044 & .760 \\
\hline Frequency of church attendance & .161 & .040 & .708 \\
\hline
\end{tabular}

Principal component analysis; varimax-rotation; factors with Eigenvalue $>1$ only; the three factors explain $65 \%$ of overall variance. Highlighted are the factor values with the highest loadings.

Fig. 1: Municipal identity as a multidimensional construct (factor analysis)

With the variables used here, we can indeed see three dimensions of municipal identity: individuals indicating a strong attachment to their municipalities or neighborhoods, and showing general satisfaction with their life in the municipality display a high attitudinal attachment. These three variables are therefore subsumed under 'affective attachment'. Frequent discussions and mutual help among neighbors can be interpreted as strong informal integration. Both variables are subsumed under factor 2, called 'informal integration' . Association members and churchgoers are considered to be formally integrated. The third factor subsumes these two variables, which will be included as 'formal integration' in the subsequent analyses.

In order to account for the multi-dimensionality of the phenomenon, the factor scores will be used as dependent variables in the following analyses. In other words, using multiple regression, factor scores will be estimated for each individual. The factor scores are easy to interpret. Factor scores above 0 indicate a value above average, while factor scores below 0 indicate values below average.

\section{Determinants of municipal identity}

How can we explain these three dimensions of municipal identity? If municipal identity is considered a fundamental prerequisite for local democracy, we should ask how affective attachment and informal and formal integration can be fostered. In the literature on municipal identity, we find at least four explanatory approaches: the 'community' approach, the 'community of limited liability' approach, the 'decline of community' approach and the 'frame of action' approach.

\section{1 'Community': spatial mobility as a determinant of municipal identity}

As a central determinant of the development of municipal identity, the 'community' approach places the emphasis on spatial mobility. It is suggested that this negatively influences municipal identity and integration into the social municipal environment, both in the form of residential mobility (change of residence) and commuter mobility. 
On the one hand, municipal attachment is supposed to result from the duration of residence (Fischer et al. 1977, p. 191; Kasarda and Janowitz 1974, p. 330; Sampson 1988, p. 767). Accordingly, people living in the same place for a long time and therefore exhibiting no residential mobility not only develop a stronger attachment to their place of residence, but also a better integration into their social environment. "The longer people had lived in an area, the more likely they were to report feeling attached" (Gerson et al. 1977 , p. 143). The duration of residence goes hand in hand with an increased likelihood to meet other people, to make friends and to join associations. In other words, the longer somebody has lived in the same place, the higher are the chances that strong informal and formal networks are established. Changes of place of residence serve as an obstacle to the establishment of social ties (Kasarda and Janowitz 1974, p. 330).

On the other hand, commuter mobility is seen as a hindrance to the development of municipal identity (Schaff 1952). Commuters are less strongly rooted, less dependent on their municipality in terms of income and therefore less interested in local happenings (Fischer 1991, p. 85). Furthermore, a high percentage of commuters in dormitory municipalities contributes to the feeling of economic dependence from working municipalities, which in turn has an overall negative effect on an individual's attitudinal attachment. As early as 1952, Schaff (1952, p. 217) was able to demonstrate that commuters are rarely active in associations. He attributes this to the fact that the interests of commuters are divided between place of residence and place of work, that they are rarely reachable due to their mobility, and therefore less exposed to opportunities of municipal social interaction. In consequence, due to the bifurcation of their lives towards different municipal contexts attachment of commuters is low (Humphries 2001, p. 680).

Obviously the 'community' approach does not explain municipal identity solely on the basis of individual mobility. Instead, it assumes that the feeling of attachment and social integration is also influenced by the overall municipal degree of mobility (Sampson 1988, pp. 767-768). Frequent residential migration, as well as a high percentage of commuters, weaken the stability of a municipality, which in turn has an impact on the behavior of individuals living in that municipality.

Humphries (2001, p. 681) raises two arguments with respect to the influence of commuting. First, the behaviour of commuters influences the behaviour of other community residents. This influence is particularly strong when the proportion of commuters is high. Second, a dormitory municipality is "a de facto satellite of another community, economically at least, if not socially as well" which also leads to a lower overall affective attachment to the municipality.

Putnam (2000, pp. 204-205) argues that municipalities with high residential and workrelated mobility have a lower integrative effect: "Mobile communities seem less friendly to their inhabitants than do more stable communities." He finds a number of negative impacts of the share of commuters on civic and political activities.

Sampson (1988, p. 774) shows that in communities with high residential mobility, even individuals having lived in that community for a long time exhibit weaker ties to their neighborhood. Communities which rapidly change due to spatial mobility have a disintegrating and destabilizing effect. This in turn has an impact on individual municipal 
identity. ${ }^{4}$ Furthermore, the probability of social interactions and integration decreases in less stable communities: "an individual in all likelihood has fewer opportunities to form friendships and to participate in local affairs in areas of high residential turnover." (Sampson 1988, p. 768).

It can be concluded that the effects of individual mobility on the attachment to a municipality can be reinforced through aggregate-level mobility. In other words, we expect a cross-level interaction. The higher the spatial (circular and residential) mobility in a community, the more negative are the effects of individual work mobility on municipal identity, that is, the weaker are the positive effects of the duration of residence on municipal attachment. To sum up, we can deduce five hypotheses:

H1: Individuals living in the same place of residence for a long time exhibit a stronger municipal identity than people changing their place of residence.

$H 2$ : Individuals living and working in the same place exhibit a stronger municipal identity than commuters.

H3: In municipalities with a small share of commuters and low residential mobility, inhabitants develop a stronger municipal identity than in municipalities with a high share of commuters and a large residential turnover.

H4: The higher the share of commuters, the higher is the negative effect of individual work mobility on municipal identity.

H5: The higher the aggregate-level residential turnover, the weaker is the positive effect of the duration of residence on the municipal identity.

\section{2 'Community of limited liability': municipal identity as a function of self-interests}

Within the approach of 'community of limited liability' (Lee et al. 1984, p. 1163; Bolan 1997 , p. 225), municipal identity is seen as a consequence of self-interest. Admittedly, according to this approach the attachment with a community declines with increasing modernity and urbanization. The identification with a municipality does not completely disappear however, but evolves when self-interest has to be defended (Gerson et al. 1977; Lindenfeld 1964). When the self-interests of a household are satisfied - so the approach goes-little incentive exists to take interest in local politics and to actively participate. "Home ownership and raising children influence individuals' feelings about and social involvements in a community" (Bolan 1997, p. 225). In other words, it is rational for home owners (Ringel and Finkelstein 1991, p. 179) and parents of school-aged children (Gerson et al. 1977) to show interest in municipal happenings und to integrate in community life (Greer 1962, p. 98; Hunter and Suttles 1972, p. 51). Consequently, a stronger attitudinal attachment with the municipality should result. Interests are furthermore best defended through cooperation. Thus self-interest should lead to stronger formal and informal integration.

The following hypotheses can be deduced:

H6: Parents of school-aged children exhibit a stronger municipal identity than individuals without children.

4 In this article we cannot take into consideration dynamic changes due to the unavailability of the respective data. 
H7: Home owners exhibit a stronger municipal identity than tenants.

\section{3 'Decline of community' as a result of increasing urbanization}

The size and urbanity of a municipality occupy a central role in explaining the attachment to one's place of residence in the 'decline of community' approach. Following the tradition of Toennies ([1887] 1991) and Wirth (1938), the population size of a municipality is seen as the fundamental determinant of social behaviour. The development from Gemeinschaft (community) to Gesellschaft (society) as a result of urbanization not only results in higher population density and greater heterogeneity of the population. These factors are also expected to have a negative impact on municipal identity. Increasing urbanization weakens an individual's attachment to a municipality and his or her social network (Fischer et al. 1977, pp. 101 ff.; Nie et al. 1969, pp. 818-819; Verba and Nie 1972, p. 230-233). "Just as the urban setting reduces allegiance to the family and other primary groups, so does it weaken attachment to the neighborhood" (Lee et al. 1984, p. 1162). In populous and densely populated cities, social and psychological connections that usually exist between neighbors in smaller villages are expected to dissolve (Oliver 2000, pp. 361-363). Primary contacts become fragile, friendship ties become weaker and the significance of community diminishes - so the central thesis of the approach (Wirth 1938).

An indirect interactive cross-level effect can also be expected for the size of the municipality. According to this expectation, commuters in more populous municipalities have even more difficulty in developing community ties than in smaller municipalities, where neighbourhood ties are more easily established. The positive effect of the duration of residence on municipal identity should therefore be stronger in smaller municipalities. Finally, anonymity and social disintegration are also expected to be more common in large cities than in smaller towns or villages. Homeowners and parents of school-age children should therefore be even better integrated in smaller municipalities than in populous cities.

We will therefore test the following hypotheses:

H8: The larger and more urban a municipality, the lower is the municipal identity of an individual living in that municipality.

H9: The larger a municipality, the stronger is the negative effect of an individual's commuter mobility on municipal identity.

H10: The larger a municipality, the weaker is the positive effect of the duration of residence on municipal identity.

H11: The larger a municipality, the weaker is the positive effect of being a homeowner on municipal identity.

H12: The larger a municipality, the weaker is the positive effect of having school-age children on municipal identity.

\section{4 'Frame of action' approach: context as a determinant of municipal identity}

The municipalities constitute frameworks within which individuals act. Depending on the narrowness or vastness of these opportunity structures, different individual behavior is 
possible. At the same time, these frameworks constitute limits for the impact of individual mobility and self-interest.

Research in the field of social capital has shown the importance of socio-demographic, cultural and institutional contextual framework factors on the social integration of individuals (Bühlmann and Freitag 2004, p. 344; Schofer and Fourcade-Gourinchas 2001, p. 807).

First, emphasis is put on the homogeneity of composition of a context which is shown to have different effects on communal identity. On the one hand-so the argumenthomogeneous communities seem more stable. The stronger the feeling among individuals that they have something in common with their neighbors, the stronger the feeling of attachment to the municipality. On the other hand, the incentive for the establishment of interest groups is higher in heterogeneous communities, which is not only reflected in a higher density of associations, but also in more widespread formal integration (Krassa 1995; Wilson 1986, pp. 1155-1156).

Second, the cultural context of a municipality plays an important role in social integration. In the Swiss context, language and religious denomination are especially important. In this regard, Freitag (2001, p. 87) comes to the conclusion that informal ties are more pronounced in the French and Italian-speaking parts of the country, while social integration in the form of formal membership is more common in the German-speaking regions. Since French and Italian speakers constitute a minority at national level, it can be expected that the attachment to a municipality is higher in the non-German-speaking municipalities. For minorities, the municipality - as a location of identification - is more important than the overall country.

Religious denomination is also important for the formal integration. A positive impact on formal integration is attributed to the liberal tradition of Protestantism (Uslaner 2002, p. 88). Bühlmann and Freitag (2004, p. 343) show however that membership of associations is more common in Catholic dominated regions. The authors attribute this to the fact that - at least in the Swiss context - important preconditions (facilities, staff, and opportunities for different activities) for social activities are more often provided by the Catholic Church then by the Protestant Church.

Third, the political institutional context is expected to have a further beneficial impact on social integration. Emphasis is put on the openness of a political system. The more numerous the possibilities of political participation, the stronger are the incentives for the establishment of and membership of formal associations (Bühlmann and Freitag 2004, p. 343). Furthermore, in a context of highly developed direct democratic participation rights, willingness of neighbors to establish contacts and mutually assist each other is more widespread (Schumacher 2003).

In addition, direct democracy is expected to strengthen feelings of attachment (Stutzer and Frey 2000), which in turn should have a positive impact on municipal identity. The Swiss context is ideal for testing the impact of direct democracy upon communal identity. In the majority of Swiss municipalities, legislative decisions are taken within the framework of public assemblies, where all citizens can take part and have their say on political issues concerning the municipality. Of course, there are also municipalities which have a municipal parliament, and where citizens do not have the same degree of direct influence. In line with studies which assume an influence of institutional contexts 
on communal identity, municipalities possessing communal assemblies should be more open and therefore contribute more to municipal identity than municipalities with parliaments (Bühlmann and Freitag 2004, p. 333).

Fourth, municipal identity depends on the macroeconomic situation, i.e. on satisfaction with local economic performance (Gerson et al. 1977). In a municipality which suffers from economic problems (e.g. high unemployment), satisfaction and municipal identity of inhabitants is low.

For the contextual variables as mentioned, we expect interactive effects as well. We will test the following hypotheses:

H13: The more homogenous the composition of a municipality, the stronger the municipal identity of an individual living in that municipality.

H14: The fewer German speaking inhabitants live in a municipality, the stronger the municipal identity of an individual living in that municipality.

H15: The fewer protestant inhabitants live in a municipality, the stronger the municipal identity of an individual living in that municipality.

H16: The more open the democratic system in a municipality, the stronger the municipal identity of an individual living in that municipality.

H17: The fewer economic problems a municipality has, the stronger the municipal identity of an individual living in that municipality.

H18: The more homogenous the composition of a municipality, the stronger the positive effects of the duration of residence, home ownership and parenthood, but the weaker the negative effect of individual work mobility on municipal identity.

H19: The fewer German speaking inhabitants live in a municipality, the stronger are the positive effects of the duration of residence, home ownership and parenthood but the weaker the negative effect of individual work mobility on municipal identity.

H20: The fewer protestant inhabitants live in a municipality, the stronger the positive effects of the duration of residence, home ownership and parenthood, but the weaker the negative effect of individual work mobility on municipal identity.

H21: The more open the democratic system in a municipality, the stronger the positive effects of the duration of residence, home ownership and parenthood, but the weaker the negative effect of individual work mobility on municipal identity.

H22: The fewer economic problems a municipality has, the stronger the positive effects of the duration of residence, home ownership and parenthood, but the weaker the negative effect of individual work mobility on municipal identity.

\section{Data and method}

For the following analyses, we have employed data from a survey of 1690 citizens resident in 56 municipalities in Switzerland. The survey took place in 2001 (Fors 2002). The number of possible interviews was constricted financially. Following Stoker and Bowers (2002, pp. 106-107), the number of respondents and the number of municipalities were balanced in a way that a simultaneous analysis of both individual as well as contextual effects are possible. Thus the approximately 3000 Swiss municipalities were clustered 
according to important characteristics (size, religious denomination, and language). Out of these clusters, 56 municipalities were randomly and proportionally selected. Within each of these municipalities, 30 respondents were randomly selected and interviewed (CATI). The respondents had to answer different subjects concerning local politics. ${ }^{5}$

"Too often our research ignores the effects of the legal and political context on the political behavior of individuals" (Conway 1989, p. 3). Of course, Conway's objection is no longer very new, but nevertheless prevailing. The impact of the social context on individual behaviour is not a well explored topic within the social sciences. This contribution considers local attachment to be affected by both, individual as well as contextual determinants. Thanks to the high variance in different contextual variables, Swiss municipalities are very well suited to this intention.

Multi-level analysis is the most useful method for the investigation of the simultaneous impact of individual characteristics, individual preferences and values as well as contextual determinants. For this method, a hierarchic structure of the data is not a methodological problem, however it is seen as a reproduction of a complex reality. Thus in contrast with regression analysis employed hitherto, multilevel analysis is more robust (Jones 1997; Snjiders and Bosker 1999, p. 6).

The underlying principle of multi-level modelling is that intercepts of common linear ordinary least square (OLS)-regression analysis are allowed to vary around an overall mean:

$$
\begin{gathered}
y_{i j}=\beta_{0 j}+\beta_{1} X_{1 j i}+\varepsilon_{i j}, \text { whereas } \\
\beta_{0 j}=\beta_{0}+\mu_{0 j}\left(\mu_{0 j} \text { stands for the residuals at the contextual level }\right) .
\end{gathered}
$$

Additionally, multi-level models allow for modelling of cross-level interaction, thus measuring the influence of contextual factors upon the strength of the connection between response and predictor variables at the lower level - methodologically speaking, the steepness of the slope. Schematically, the models on which the analyses are based will have this form:

$$
\begin{aligned}
y_{i j}= & \beta_{0}+\beta_{1} X_{1 i j}+\ldots+\beta_{n} X_{n i j}+\alpha_{1} W_{1 j}+\ldots \\
& +\alpha_{n} W_{n j}+\gamma_{1} W_{k j} X_{k i j}+\mu_{k j} X_{k i j} \\
& +\mu_{0 j}+\varepsilon_{i j}
\end{aligned}
$$

The municipal identity (y) of an individual $\mathrm{i}$ within a municipality $\mathrm{j}$ is explained by an overall mean of municipal identity $\left(\beta_{0}\right)$, individual characteristics $(\mathrm{X}$, their estimates $\beta$ respectively), contextual factors (W, their estimates $\alpha$ respectively), cross-level interac-

5 As a rule of thumb, to conduct multi-level analysis, one should have at least 25 objects on the higher level and at least 25 objects within each of these higher level contexts (Jones 1997; Teachman and Crowder 2002). Stoker and Bowers (2002, p. 105) further recommend a balanced sample for multilevel purposes: one should prefer a high number of contexts rather than a high number of individuals. A detailed description of the chosen municipalities can be found in Bühlmann (2006, pp. 25-27). 
tion terms with specific individual $\left(\mathrm{X}_{\mathrm{k}}\right)$ as well as contextual variables $\left(\mathrm{W}_{\mathrm{k}}\right)\left(W_{k j} X_{k i j}\right.$, their estimates $\gamma$ respectively), whereas the effect of the estimate is randomized $\left(\beta_{k j}\right)$, contextual variation $\left(\mu_{0 j}\right.$ with an assumed mean of 0 and a total between context variance of $\left.\sigma_{\mu}^{2}\right)$, individual variation $\left(\varepsilon_{i j}\right.$ with an assumed mean of 0 and a total within context variance of $\left.\sigma^{2}\right)$, and slope variation $\left(\mu_{k j} X_{k i j}\right)$. The overall variation $\left(\sigma_{\mu}^{2}+\sigma^{2}\right)$ is divided into differences at the individual level (level 1 variance), which will be explained by individual characteristics, and differences between contexts (level 2 variance), which will be explained by contextual factors, whereas the slope variance will be explained by the interaction terms.

Multi-level analysis gets over 'micro-macro dualism' and is thus well suited to simultaneously modelling the impact of individual and contextual determinants. A mere ecological or an individual analysis only could not give us satisfactory results. While simple cross-section analysis bears the danger of ecological fallacy (Robinson 1950) and does not respect the original data structure (Snijders and Bosker 1999, pp. 14-15), a simple individual regression cannot do justice to the hierarchic structure of the data (Bühlmann 2006, p. 262; Paterson and Goldstein 1992) and underestimates the standard errors (Hox 2010, p. 4; Teachman and Crowder 2002, p. 284). Of course, one could correct the hierarchical structure by modeling different context dummies. However, in doing this, the differences between the contexts can be modelled but not explained (Bühlmann 2006, p. 267; Steenbergen and Jones 2002, p. 220). Furthermore, estimating cross-level interactions is not possible with hitherto methods.

\section{Results}

In this section, we will test the hypotheses and approaches that were presented in Sect. 3 . In addition to the mentioned determinants, age, gender and education serve as control variables. Age and education in particular are seen as important determinants of individual municipal identity (Gerson et al. 1977). The three dimensions of municipal identity mentioned in Sect. 2 (i.e. the factor values for each individual on 'affective attachment', 'informal integration' and 'formal integration') will be used as dependent variables.

To test the hypotheses, we proceed in three steps. First, we test with empty models whether the three dimensions of municipal identity indeed vary between the municipalities. In a second step, we analyse the fixed effects models i.e. we model simultaneously the direct effect of the individual and contextual determinants of the four approaches on an individual's municipal identity. At the same time, we check for differences between the municipalities. The third step consists of the tests of the cross-level interaction hypotheses.

The results of the empty models are presented in Table 1 . With respect to all three factors we can see that the variance is in large part due to differences between individuals. A significant part of the variance - between 3\% and 5\% of the total variance - can, however, be explained by differences between the municipalities. In the following models, we test which of the expected determinants actually exert a significant influence.

Looking at Table 2, we notice the different explanatory power of the determinants of the different dimensions of municipal identity. It becomes clear that municipal identity is 
Table 1: Empty models

\begin{tabular}{llll}
\hline & Affective attachment & Informal integration & Formal integration \\
\hline $\begin{array}{l}\text { Fixed effects } \\
\text { Constant }\end{array}$ & $0.00(0.03)$ & $-0.00(0.04)$ & $0.00(0.04)$ \\
$\begin{array}{l}\text { Random effects } \\
\text { Individual level }\left(\sigma^{2}\right)\end{array}$ & $0.97(0.03)$ & $0.96(0.03)$ & $0.95(0.03)$ \\
Contextual level $\left(\sigma_{\mu 0}^{2}\right)$ & $0.03(0.01)$ & $0.04(0.01)$ & $0.05(0.02)$ \\
$\begin{array}{l}\text { Model properties } \\
\text { Number of cases }\end{array}$ & 1656 & 1656 & 1656 \\
- 2log-likelihood $(\mathrm{df})$ & $4684(1)$ & $4678(1)$ & $4663(1)$ \\
\hline
\end{tabular}

Non-standardized coefficients with standard errors in brackets; italic: significant at least at the $90 \%$ level; models based on generalized least squares (IGLS)

not only a multidimensional construct, but that there are also different determinants which are important for the development of the several dimensions of municipal identity.

Spatial Mobility exerts the important influence as we expected. Individual commuting diminishes both affective attachment and formal integration, while duration of residence has the expected strengthening impact on identity. The same is not true for informal integration into the neighbourhood. Neither commuting nor duration of residence have an influence on the density of neighborly attachment. The expected negative effects of spatial mobility can also be found at the aggregate level. A large portion of commuters in a municipality reduces informal and formal integration of individuals living in such municipalities. In municipalities in which we observe pronounced population changes due to residential turnover, individuals are less formally integrated. Again, we find differences. Affective attachment is not at all affected by aggregated spatial mobility. All in all, we can argue that spatial mobility is mostly detrimental for municipal identity. This is true of both individual and aggregate residential and of circular mobility.

We also find evidence for the expected impact of self-interest: With one exception, home ownership and parenthood exert a positive influence. Only affective attachment does not increase when someone has school-age children.

As for the control variables 'age', 'gender' and 'education', these seem to have only a minor impact on the development of municipal identity. To be sure, informal integration increases with age and women are more likely to develop an affective attachment to their municipality. Education, however, does not seem to be of any importance for the development of municipal identity. In addition, neither age nor gender is important for formal integration.

As for the contextual determinants beside aggregated mobility, municipality size shows interesting results. In line with the hypothesis introduced in the context of the 'decline of community' approach, municipality size has a negative impact on the integration of an individual into his or her municipality, be it formal or informal. In other words, an individual living in a small municipality tends to have more formal and informal contacts, and therefore more easily develops municipal identity than an individual with the exact same individual characteristics but living in a larger municipality. On the other hand, the size of a municipality fosters affective attachment. City dwellers develop stronger feelings of attachment to their municipality than inhabitants of villages. These (at first sight 
Table 2: Individual und contextual determinants of municipal identity

\begin{tabular}{|c|c|c|c|}
\hline & Affective attachment & Informal integration & Formal integration \\
\hline \multicolumn{4}{|l|}{ Fixed effects } \\
\hline Constant & $-0.39(0.38)$ & $0.34(0.31)$ & $-0.11(.22)$ \\
\hline \multicolumn{4}{|l|}{ Individual level } \\
\hline \multicolumn{4}{|l|}{ Individual mobility } \\
\hline Commuters & $-0.13(0.07)$ & $0.00(0.06)$ & $-0.13(0.06)$ \\
\hline Duration of residence & $0.01(0.00)$ & $0.00(0.00)$ & $0.01(0.00)$ \\
\hline \multicolumn{4}{|l|}{ Self-interest } \\
\hline Home ownership & $0.10(0.06)$ & $0.11(0.06)$ & $0.16(0.06)$ \\
\hline School-age children & $0.07(0.06)$ & $0.20(0.06)$ & $0.23(0.06)$ \\
\hline \multicolumn{4}{|l|}{ Control variables } \\
\hline Age & $0.00(0.00)$ & $0.01(0.00)$ & $0.00(0.00)$ \\
\hline Gender & $-0.14(0.05)$ & $0.03(0.05)$ & $0.03(0.05)$ \\
\hline Education & $-0.02(0.02)$ & $-0.00(0.02)$ & $0.00(0.02)$ \\
\hline \multicolumn{4}{|l|}{ Contextual level } \\
\hline \multicolumn{4}{|l|}{ Aggregated mobility } \\
\hline Share of commuters & $0.44(0.47)$ & $-0.75(0.38)$ & $-0.78(0.26)$ \\
\hline Residential mobility & $0.00(0.00)$ & $0.00(0.00)$ & $-0.01(0.00)$ \\
\hline \multicolumn{4}{|l|}{ Size } \\
\hline Population size (log) & $0.09(0.04)$ & $-0.09(0.03)$ & $-0.11(0.02)$ \\
\hline \multicolumn{4}{|l|}{ Contextual framework } \\
\hline \multicolumn{4}{|l|}{ Homogeneity of composition } \\
\hline Share of migrants & $-0.00(0.01)$ & $0.00(0.01)$ & $0.01(0.00)$ \\
\hline Ideological homogeneity & $-0.08(0.22)$ & $-0.36(0.17)$ & $0.49(0.12)$ \\
\hline \multicolumn{4}{|l|}{ Cultural context } \\
\hline Share of German speakers & $-0.19(0.11)$ & $0.16(0.09)$ & $0.44(0.06)$ \\
\hline Share of Catholics & $-0.20(0.14)$ & $-0.17(0.11)$ & $0.38(0.08)$ \\
\hline \multicolumn{4}{|l|}{ Institutional context } \\
\hline Municipal assembly & $-0.07(0.10)$ & $0.14(0.08)$ & $0.15(0.05)$ \\
\hline $\begin{array}{l}\text { Macroeconomic context } \\
\text { Unemployment rate }\end{array}$ & $-0.15(0.08)$ & $0.05(0.06)$ & $0.06(0.04)$ \\
\hline \multicolumn{4}{|l|}{ Random effects } \\
\hline Individual level $\left(\sigma^{2}\right)$ & $0.86(0.03)$ & $0.93(0.04)$ & $0.87(0.03)$ \\
\hline Contextual level $\left(\sigma_{\mu 0}^{2}\right)$ & $0.16(0.07)$ & $0.00(0.00)$ & $0.10(0.05)$ \\
\hline
\end{tabular}


Table 2: (continued)

\begin{tabular}{llll}
\hline & Affective attachment & Informal integration & Formal integration \\
\hline $\begin{array}{l}\text { Slope variances } \\
\text { Individual mobility }\end{array}$ & & & \\
$\quad$ Commuters & $0.07(0.04)$ & $0.03(0.02)$ & $0.04(0.04)$ \\
$\quad \begin{array}{l}\text { Duration of residence } \\
\text { Self-interest }\end{array}$ & $0.00(0.00)$ & $0.00(0.00)$ & $0.00(0.00)$ \\
$\quad$ Home ownership & $0.04(0.03)$ & $0.00(0.02)$ & $0.05(0.03)$ \\
$\quad$ School-age children & $0.00(0.00)$ & $0.00(0.00)$ & $0.00(0.00)$ \\
Model properties & & & 1526 \\
Number of cases & 1526 & 1526 & $4115(17)$ \\
-2 log-likelihood (df) & $4172(17)$ & $4215(17)$ & 30.2 \\
Maddala-R $^{2}$ & 30.6 & 26.2 & \\
\hline
\end{tabular}

Non-standardized coefficients with standard errors in brackets; italic: significant at least at the $90 \%$ level; models based on generalized least squares (IGLS). Maddala- $\mathrm{R}^{2}$ based on deviance: the value depicts the share of explained variance within the model compared to the empty model in Table 1

contradictory) results, can be explained by means of 'social interaction': both formal and informal integration require social interaction. It is precisely this contact with other people which, according to the 'decline of community' approach, decreases with increasing population size. Affective attachment, on the other hand, does not require interaction with others. Besides, the infrastructural and cultural opportunities available in cities are most likely to have a positive impact on individual satisfaction with life in a city. This constitutes an important component of affective attachment.

In addition to the aggregate mobility and the size of a municipality, all other contextual determinants exert a certain influence. Again, we find important differences between the three dimensions of municipal identity:

Ideological homogeneity seems to foster formal integration. The same, however, is not true of informal integration. Even formal integration is, however, strengthened by heterogeneity when ethnic composition is taken into consideration. The effect of ideological heterogeneity upon informal integration can be explained through the stimulating effect of ideological differences on political discussions. Homogeneity, on the other hand, has no effect on affective attachment.

The cultural context is also important for the manifestation of municipal identity. Table 2 hints at an influence of cultural differences on municipal identity. Whereas in German speaking municipalities, it seems to be formal and informal integration which foster municipal identity, in French- and Italian-speaking municipalities, affective attachment is more widespread. A high percentage of Catholics seems to have a positive impact on formal integration ${ }^{6}$, but has no influence neither on informal integration nor affective attachment.

6 In line with Bühlmann and Freitag (2004), we assume that this result is not necessarily due to the frequency of church visits as a component of the 'formal integration' factor. The authors 
The openness of the political system, approximately measured with the presence of a municipal assembly (in contrast to a municipal parliament), seems to foster both formal and informal integration. As expected, a local political system with direct democratic mechanisms seems to foster communication between individuals, create incentives for the organization of interests in associations, and thereby strengthen the municipal identity of an individual through informal and formal integration. However, the institutional context seems to be of no importance for the development of affective attachment to the municipality.

As expected, the economic situation, as measured by high unemployment, also has an impact on municipal identity. The higher the unemployment rate in a municipality, the weaker the affective attachment of an individual living in that municipality. This can be attributed to lower satisfaction with life in municipalities with high unemployment.

Overall, the variables included in the models explain about $25-30 \%$ of the variance as compared to the empty models. This suggests that there are other explanatory factors which influence municipal identity. Moreover, the variables analyzed in these models seem to explain somewhat better two of the three dimensions of municipal identity, i.e. affective attachment and formal integration.

Looking at the random effects in Table 2, we can see that at least part of the individual variance is explained by individual-level factors (see the lower variance share of the individual level when compared to the empty models in Table 1). With the exception of informal integration, contextual variance has increased. This is owing to the fact that the central individual variables (of mobility and self-interest) have been modelled with varying slopes. The analysis shows that the effects of work mobility and residential mobility as well as of home ownership differ between municipalities. In other words, the strength of the negative effect of individual commuter mobility on affective attachment and the strength of the positive impact of duration of residence and home ownership on formal integration differ between communities. This variance is due to differences between the municipalities. $^{7}$

At the same time, these slope variances constitute the empirical requirement for the examination of the postulated cross-level interaction. By modelling these interactive contextual impacts, we can answer the follow-up question of which municipality characteristics explain the differing effects of the discussed individual determinants. These models can be found in Table 3 .

Before commenting on the results in Table 3, it should be emphasized that the individual and contextual factors do not have the same meaning as interaction terms as they did in Table 2. In the following, we will therefore interpret only the interaction terms and the random effects.

From the results, we can see that most interaction terms do not have the expected explanatory power. In particular, contextual mobility fails to explain the differences in

show that the probability of being a member of associations is higher in catholic municipalities than in municipalities with a low share of Catholics. An additional multi-level analysis (not presented here) which only included one of the two variables of the 'formal integration' dimension (membership of associations) confirms these results.

7 Parenthood shows no significant slope variance and is therefore not included in the following analyses. 
Table 3: Individual, contextual and interactive determinants of municipal identity

\begin{tabular}{|c|c|c|c|}
\hline & Affective attachment & Formal integration 1 & Formal integration 2 \\
\hline \multicolumn{4}{|l|}{ Fixed effects } \\
\hline Constant & $0.56(0.65)$ & $0.30(0.45)$ & $0.21(0.44)$ \\
\hline \multicolumn{4}{|l|}{ Individual level } \\
\hline \multicolumn{4}{|l|}{ Individual mobility } \\
\hline Commuters & $-1.38(0.74)$ & $-0.14(0.06)$ & $-0.13(0.06)$ \\
\hline Duration of residence & $0.01(0.00)$ & $-0.01(0.02)$ & $0.01(0.00)$ \\
\hline \multicolumn{4}{|l|}{ Self-Interest } \\
\hline Home ownership & $0.10(0.05)$ & $0.16(0.05)$ & $-0.27(0.59)$ \\
\hline School-age children & $0.07(0.06)$ & $0.24(0.06)$ & $0.23(0.06)$ \\
\hline \multicolumn{4}{|l|}{ Control variables } \\
\hline Age & $0.00(0.00)$ & $0.00(0.00)$ & $0.00(0.00)$ \\
\hline Gender & $-0.15(0.05)$ & $0.04(0.05)$ & $0.03(0.05)$ \\
\hline Education & $-0.02(0.02)$ & $0.00(0.02)$ & $0.00(0.02)$ \\
\hline \multicolumn{4}{|l|}{ Contextual level } \\
\hline \multicolumn{4}{|l|}{ Aggregated mobility } \\
\hline Share of commuters & $-0.27(0.81)$ & $-1.02(0.60)$ & $-0.85(0.54)$ \\
\hline Residential mobility & $0.01(0.01)$ & $-0.01(0.00)$ & $-0.01(0.01)$ \\
\hline \multicolumn{4}{|l|}{ Size } \\
\hline Population size (log) & $-0.02(0.07)$ & $-0.10(0.05)$ & $-0.13(0.05)$ \\
\hline \multicolumn{4}{|l|}{ Contextual framework } \\
\hline \multicolumn{4}{|l|}{ Homogeneity of composition } \\
\hline Share of migrants & $0.00(0.01)$ & $0.00(0.01)$ & $0.00(0.01)$ \\
\hline Ideological homogeneity & $-0.09(0.38)$ & $0.33(0.27)$ & $0.24(0.27)$ \\
\hline \multicolumn{4}{|l|}{ Cultural context } \\
\hline Share of German speakers & $-0.02(0.21)$ & $0.34(0.14)$ & $0.38(0.14)$ \\
\hline Share of Catholics & $-0.29(0.24)$ & $0.00(0.19)$ & $0.31(0.19)$ \\
\hline \multicolumn{4}{|l|}{ Institutional context } \\
\hline Municipal assembly & $-0.24(0.17)$ & $0.10(0.12)$ & $0.12(0.12)$ \\
\hline \multicolumn{4}{|l|}{ Macroeconomic context } \\
\hline Unemployment rate & $-0.08(0.13)$ & $0.06(0.10)$ & $0.15(0.09)$ \\
\hline \multicolumn{4}{|l|}{ Interaction terms } \\
\hline $\begin{array}{l}\text { Proportion of commuters * } \\
\text { commuters }\end{array}$ & $0.96(0.96)$ & - & - \\
\hline $\begin{array}{l}\text { Residential mobility * dura- } \\
\text { tion of residence }\end{array}$ & - & $0.00(0.00)$ & - \\
\hline
\end{tabular}


Table 3: (continued)

\begin{tabular}{|c|c|c|c|}
\hline & Affective attachment & Formal integration 1 & Formal integration 2 \\
\hline $\begin{array}{l}\text { Population size } * \text { commut- } \\
\text { ers/duration of residence/ } \\
\text { home ownership }\end{array}$ & $0.13(0.08)$ & $0.00(0.00)$ & $0.02(0.06)$ \\
\hline $\begin{array}{l}\text { Share of migrants } * \text { com- } \\
\text { muters/duration of residence/ } \\
\text { home ownership }\end{array}$ & $0.00(0.01)$ & $0.00(0.00)$ & $0.02(0.01)$ \\
\hline $\begin{array}{l}\text { Ideology } * \text { commuters/du- } \\
\text { ration of residence/home } \\
\text { ownership }\end{array}$ & $-0.02(0.44)$ & $0.00(0.01)$ & $0.32(0.36)$ \\
\hline $\begin{array}{l}\text { German Speakers * commut- } \\
\text { ers/duration of residence/ } \\
\text { home ownership }\end{array}$ & $-0.23(0.24)$ & $0.01(0.01)$ & $0.14(0.19)$ \\
\hline $\begin{array}{l}\text { Catholics * commuters/du- } \\
\text { ration of residence/home } \\
\text { ownership }\end{array}$ & $0.24(0.29)$ & $0.02(0.01)$ & $0.15(0.24)$ \\
\hline $\begin{array}{l}\text { Municipal assemblies * com- } \\
\text { muters/duration of residence/ } \\
\text { home ownership }\end{array}$ & $0.24(0.20)$ & $0.00(0.00)$ & $0.05(0.16)$ \\
\hline $\begin{array}{l}\text { Unemployment rate } * \text { com- } \\
\text { muters/duration of residence/ } \\
\text { home ownership }\end{array}$ & $-0.13(0.16)$ & $0.00(0.00)$ & $-0.18(0.13)$ \\
\hline \multicolumn{4}{|l|}{ Random effects } \\
\hline Individual level $\left(\sigma^{2}\right)$ & $0.88(0.03)$ & $0.87(0.03)$ & $0.88(0.03)$ \\
\hline Contextual level $\left(\sigma_{\mu 0}^{2}\right)$ & $0.04(0.03)$ & $0.00(0.00)$ & $0.00(0.00)$ \\
\hline \multicolumn{4}{|l|}{ Slope variances } \\
\hline \multicolumn{4}{|l|}{ Individual mobility } \\
\hline Commuters & $0.05(0.04)$ & - & - \\
\hline Duration of residence & - & $0.00(0.00)$ & - \\
\hline \multicolumn{4}{|l|}{ Self-interest } \\
\hline Home ownership & - & - & $0.00(0.00)$ \\
\hline \multicolumn{4}{|l|}{ Model properties } \\
\hline Number of cases & 1526 & 1526 & 1526 \\
\hline -2log-likelihood (df) & $4179(26)$ & $4126(26)$ & $4139(26)$ \\
\hline Maddala- $\mathrm{R}^{2}$ & 28.2 & 30.4 & 29.1 \\
\hline
\end{tabular}

Non-standardized coefficients with standard errors in brackets; italic: significant at least at the as follows: column 1: contextual determinant * individual commuting; column 2: contextual determinant * length of residence; column 3: contextual determinant * home ownership; Maddala- $\mathrm{R}^{2}$ based on deviance: the value depicts the share of explained variance within the model compared to the empty model in Table 1 
the effects of individual mobility and self-interest. However, three municipality traits, namely population size, cultural context in the form of denominational predominance, and homogeneity in the form of ethnic composition are found to be important for the explanation of the differences in the strength of the effects.

The larger a municipality, the weaker the negative effect of individual commuter mobility on the affective attachment to a municipality becomes. A high number of inhabitants attenuate the negative impact of individual work mobility on the affective attachment to a municipality. This, once again, shows the positive impact of the municipality size on the development of feelings of attachment to one's municipality.

With respect to informal attachment, we find no differing impacts of the four individual determinants. Duration of residence (column 3: model 'formal integration 1') and home ownership (column 4: model 'formal integration 2') however exhibit, differing impacts on formal integration. These can be explained by the share of Catholics and migrants in a municipality.

The higher the share of Catholics, or the higher the share of migrants in a municipality, the stronger is the effect of duration of residence or home ownership on formal integration. A catholic environment does not only seem to strengthen formal integration, but the integrative impact of duration of residence is also reinforced. The catholic environment thus serves as a multiplier.

The impact of ethnic composition can be interpreted in different ways. On the one hand, we can suspect that on the basis of the 'mobilisation approach' and the counter model of the 'decline of community' approach (Verba and Nie 1972; Chap. 13) - heterogeneity constitutes an amplifier for individual social interaction and activity. This would mean that multi-cultural contexts intensify the positive effect of home ownership on formal integration even further. On the other hand, a simple aggregate analysis of the 56 municipalities shows a significant and highly negative correlation between home ownership rates and the share of migrants in a municipality. Within the context of the 'community of limited liability' approach, home ownership is regarded as self-interest, and it is postulated that municipal identity is developed when self-interest is regarded as being threatened. In this sense, it could also be hypothesized that a high share of foreigners in a municipality is seen as a threat, and home ownership therefore leads to an even stronger formal integration in order to safeguard one's own interests. ${ }^{8}$

Again, by introducing these variables, $30 \%$ of the variance is explained as compared to the empty model. This time, we only find minor differences between the three dimensions of municipal identity.

The cross-level interactions explain the slope variance of the three individual determinants (commuters, duration of residence and home ownership) which are no longer significant after the introduction of the interaction terms. Moreover, we no longer have significant contextual level variances in the three models. This can be interpreted as a sign of a relatively well saturated model — at least with regard to the contextual level and slope variances.

8 Contrary to this finding however, Wimmer et al. (2000) show that dissatisfaction is high in municipalities with a low share of migrants whereas in municipalities with a high share of migrants, there is much more tolerance. 
On the whole, the low contextual variance and the insignificance of most interaction terms lead us to the conclusion that the contextual level most probably does not have the same importance for the creation of municipal identity as does the individual level. The first-time systematic test of contextual factors does show some expected effects of different contextual determinants, but individual municipality identity is more strongly influenced by characteristics and attitudes of the individual. This assumption is enforced by the observation that there are only weak improvements of the model fit when crosslevel interactions are included in the model. Individual effects seem to unfold their impact quite similarly in all municipalities.

\section{Summary and conclusions}

The main topic in this study has been municipal identity, i.e. the attachment to the municipalitiy one lives in. The results suggest high variance of municipal identity between different individuals as well as between different municipalities. The main aim of the article has been to explain this variance. It was suggested that mobility plays a key role in an individual's municipal identity. It is also suggested that spatial mobility in terms of circular (commuting) and residential mobility (change of place of residence) has a negative effect on the feeling of local identity. Furthermore, we analysed whether municipal identity is a function of self-interest or of the local context. With different multilevel analyses, we modeled the impact of individual as well as of contextual determinants on municipal identity.

In a preceding step, we showed that municipal identity in fact is a multi-dimensional concept consisting of at least three dimensions. Attitudinal attachment is based upon the sentiment of attachment to a municipality and to one's neighborhood, as well as upon satisfaction with one's life in the municipality. Behavioral attachment can be divided into formal and informal integration. Individuals who are informally integrated show a high frequency of neighborhood contacts. The degree of formal integration depends on membership of associations, and the frequency of church attendance.

The empirically found multi-dimensionality of the concept confirms findings from the literature (Bolan 1997; Gerson et al. 1977; Kasarda and Janowitz 1974; Taylor et al. 1984; Sampson 1988; Stinner et al. 1990; Woolever 1992). Consequently, three dimensions are used separately as dependent variables.

As for mobility, we observe at least in part the negative impact as suggested by the 'community' approach. Commuters and individuals who change their residence have less municipal identity, both in terms of affective attachment as well as formal integration. Furthermore, individuals living in dormitory municipalities and municipalities with high residential turnover are less formally and informally integrated. There is also some confirmation of the 'Community of Limited Liability' approach. Individual interests in terms of home ownership foster municipal identity in its three-dimensionality, whereas parenthood goes hand in hand with formal and informal integration.

The size of a municipality has different impacts. On the one hand, and according to the 'Decline of Community' approach, individuals' formal as well as informal integration decreases with increasing municipality size. On the other hand, affective attachment is higher in bigger municipalities. The feeling of attachment as well as satisfaction with 
life in a municipality is bigger in towns whereas social networks are tighter in villages. Furthermore, growing size has an attenuating impact on the negative effect of individual commuting on affective attachment.

The multi-level analyses also show different impacts of further contextual variables on municipal identity. Individuals living in German-speaking municipalities and/or municipalities with high unemployment develop less affective attachment then citizens of French and Italian-speaking municipalities with low unemployment.

Informal integration is positively affected by ideologically heterogeneous, Germanspeaking and municipalities organized more upon direct democracy. Ideological heterogeneity as well as opportunities for more direct participation seems to encourage discussions - an element of informal integration.

On the contrary, formal integration is fostered by the share of immigrants, ideological homogeneity, and direct democratic settings. Additionally, the German language as well as the Catholic culture also has a positive effect on formal social capital. Again, we find some interactive effects. The higher the share of Catholics and of immigrants in a municipality, the stronger the positive effect of the length of residence and of homeownership on an individual's formal integration becomes.

These results form the basis of four conclusions:

First, multi-dimensionality of municipal identity is of crucial importance. The results show that the dimensions cannot be treated similarly. Different (mainly contextual) factors have at least in part opposed impacts on different elements of municipal identity. Future research on attachment should bring more clarity to the complexity of this phenomenon.

Second, to explain individual municipal identity, one should not only look at individual factors, but also at contextual ones. Men are not hermits, but they do live in social contexts that differ in terms of cultural, political, or economic circumstances. Such circumstances can be seen as frames that can be more or less narrow, thus allowing more or less individual action.

Third, the contribution shows that all approaches - the 'Community of Limited Liability', the 'Decline of Community' as well as the 'frame of action' approach account for the explanation of municipal identity. Thus the results suggest a triangulation of different approaches rather than an 'either-or' research strategy.

Fourth, the results also suggest policy implications. There are possibilities to foster municipal identity which can be seen as an important feature of the functioning of local civil and political society - at least for Switzerland. Provisions which allow for working and residing within the same municipality, as well as the extension of opportunities for direct participation are suggested to foster the citizen's municipal identity.

Of course, the question is whether these Swiss results are generalizable for other countries. The small-scale settings, the high autonomy and the institutional singularity of Swiss local political systems seem to prejudice the transferability of the results. However, Swiss municipalities could also be seen a natural laboratory: the variance with respect to the size, social composition or mobility is similar in other countries. Finally, the question of generalizability must be answered empirically. This contribution has shown possible paths for such endeavors. Investigations in other countries should at least take into account the multi-dimensionality of municipal identity, the importance of contextual settings, and should include different approaches. 


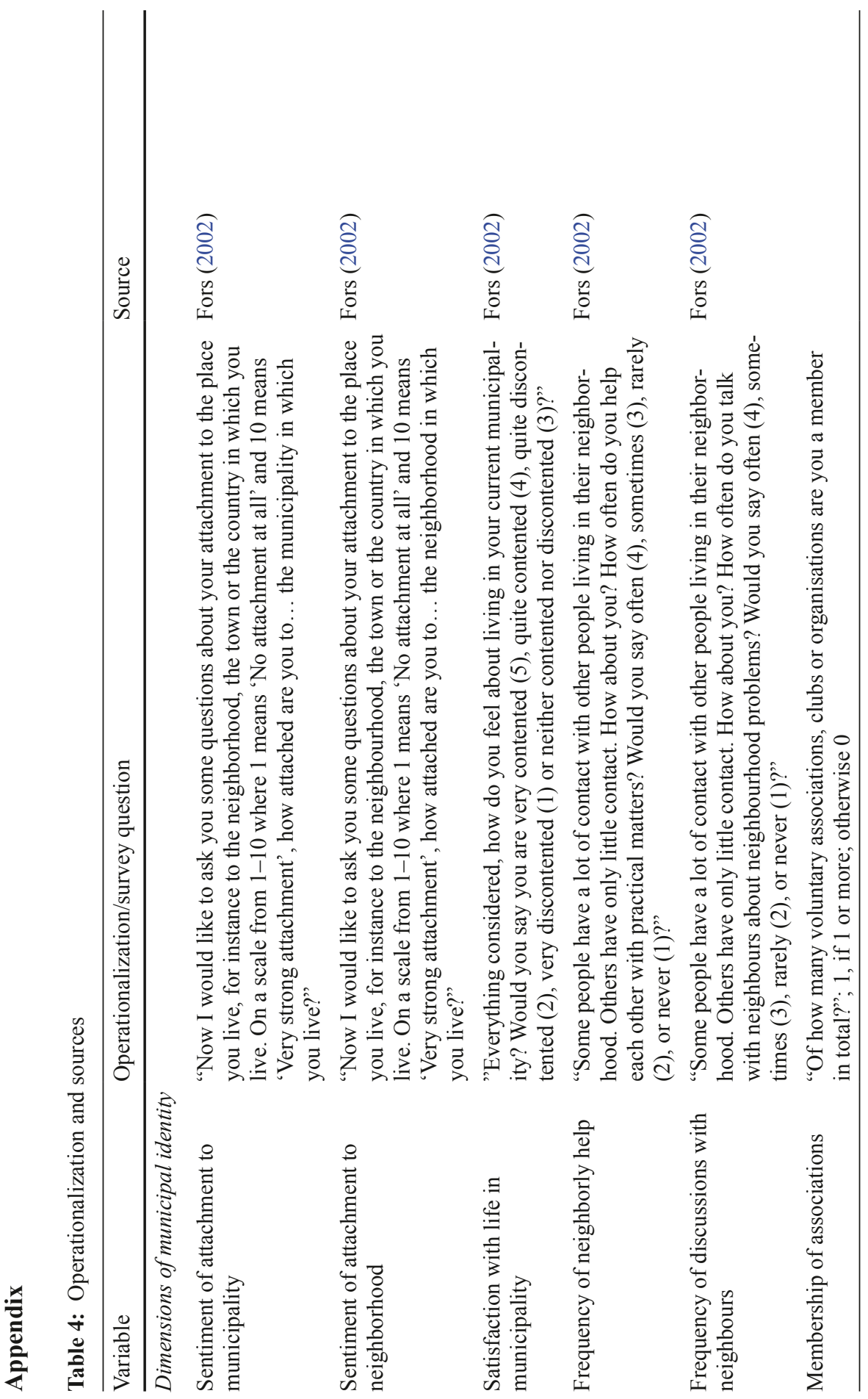




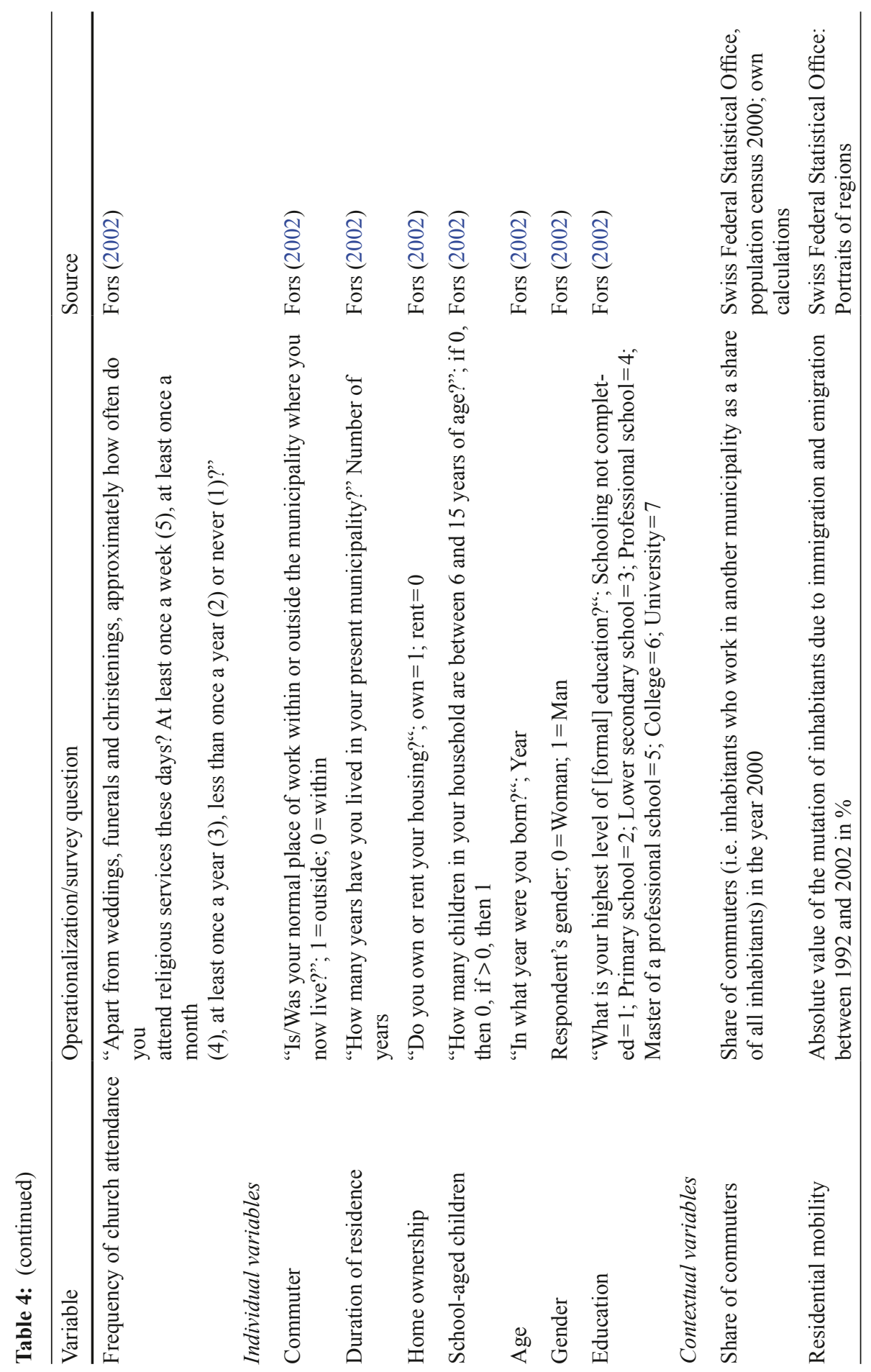




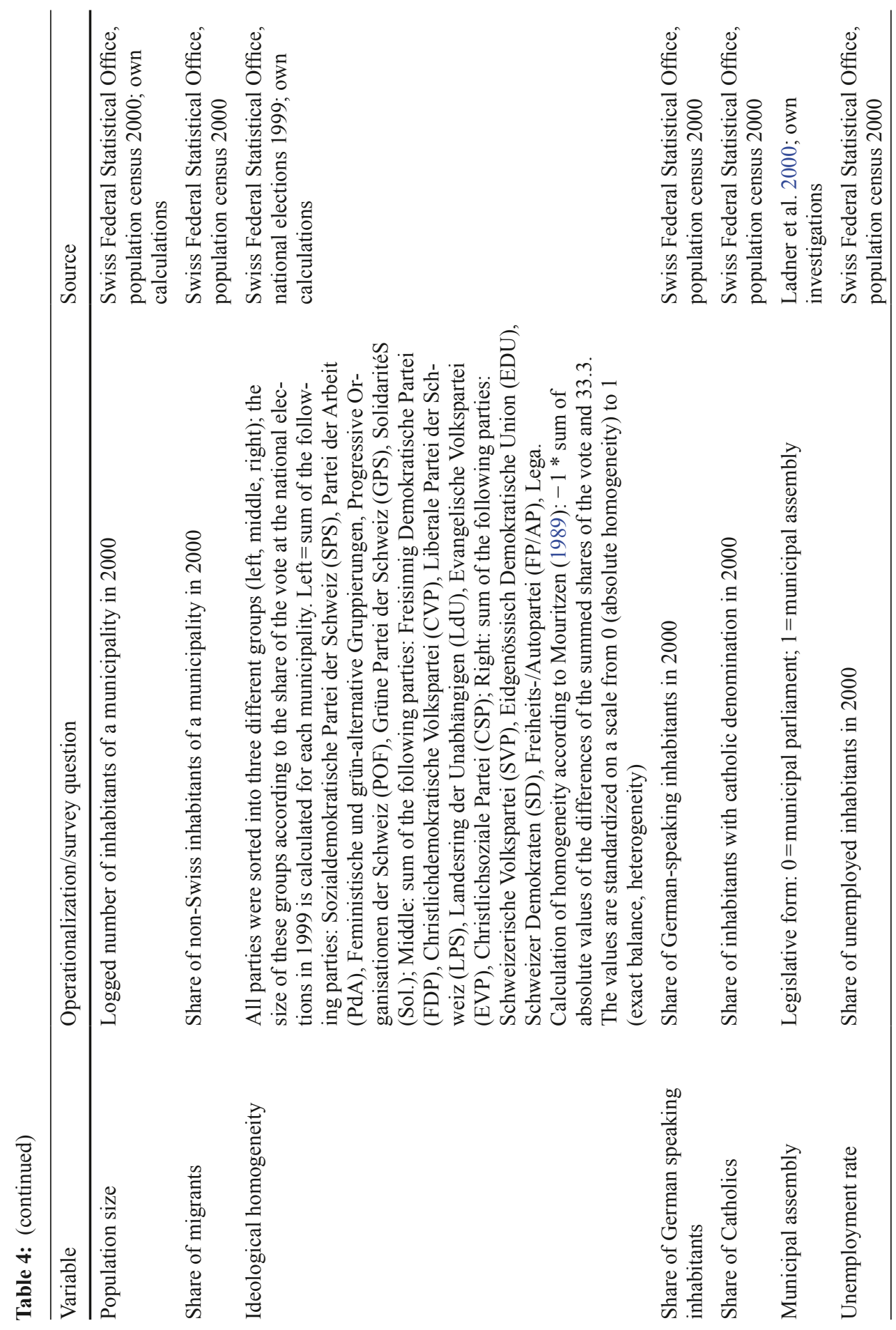




\section{References}

Backhaus, Klaus, Bernd Erichson, Wulff Plinke, and Rolf Weiber. 2000. Multivariate Analysemethoden. Eine anwendungsorientierte Einführung. Berlin: Springer.

Barber, Benjamin R. 1994. Starke Demokratie. Über die Teilhabe am Politischen. Hamburg: Rotbuch.

Bassand, Michel, Anne Compagnon, Dominique Joye, Véronique Stein, and Peter Güller. 2001. Vivre et créer l'espace public. Lausanne: Presses polytechniques et universitaires romand.

Bolan, Marc. 1997. The mobility experience and neighborhood attachment. Demography 34 (2): 225-237.

Bühlmann, Marc. 2006. Politische Partizipation im kommunalen Kontext-Der Einfluss lokaler Kontexteigenschaften auf individuelles politisches Partizipationsverhalten. Bern: Haupt.

Bühlmann, Marc, and Markus Freitag. 2004. Individuelle und kontextuelle Determinanten der Teilhabe an Sozialkapital. Eine Mehrebenenanalyse zu den Bedingungen des Engagements in Freiwilligenorganisationen. Kölner Zeitschrift für Soziologie und Sozialpsychologie 56 (2): 326-349.

Coleman, James. 1986. Social theory, social research, and a theory of action. American Journal of Sociology 91:1309-1335.

Coleman, James. 1991. Grundlagen der Sozialtheorie. München: R. Oldenbourg Verlag.

Conway, M. Margaret. 1989. The political context of political behavior. The Journal of Politics 51 (1): $3-10$.

Fischer, Claude S. 1991. Ambivalent communities: How Americans understand their localities. In America at century's end, ed. Alan Wolfe, 79-92. Berkeley: University of California Press.

Fischer, Claude S., Robert Max Jackson, C. Ann Stueve, Kathleen Gerson, and Lynne McAllister Jomes. 1977. Networks and places: Social relations in the urban setting. New York: Free Press.

Fors. 2002. Size and Local Democracy. Datenservice; Forschungs- und Datensatzbeschreibung Projekt ID 7481. Lausanne: Swiss Foundation for Research in Social Sciences. http://forsdata.unil.ch/fw_query_fors/jd-result-2-det.fwx?lang=D\&htm.sel0=7481. Accessed 26 March 2010.

Freitag, Markus. 2001. Das soziale Kapital der Schweiz. Vergleichende Einschätzungen zu Aspekten des Vertrauens und der sozialen Einbindung. Schweizerische Zeitschrift für Politische Wissenschaft 7 (4): 87-117.

Freitag, Markus. 2005. Labor Schweiz: Vergleichende Wahlbeteiligungsforschung am Beispiel der kantonalen Parlamentswahlen. Kölner Zeitschrift für Soziologie und Sozialpsychologie 57 (4): 667-690.

Gabriel, Oscar W., Volker Kunz, Sigrid Rossteutscher, and Jan W. Van Deth. 2002. Sozialkapital und Demokratie. Zivilgesellschaftliche Ressourcen im Vergleich. Wien: WUV-Universitäts-Verlag.

Gerson, Kathleen, C. Ann Stueve, and Claude S. Fischer. 1977. Attachment to place. In Networks and places: Social relations in the urban setting, ed. Claude S. Fischer, Robert Max Jackson, C. Ann Stueve, Kathleen Gerson and Lynne McAllister Jones, 139-161. New York: Free Press.

Greer, Scott. 1962. The emerging city: Myth and reality. New York: Free Press.

Hox, Joop J. 2010. Multilevel analysis. Techniques and applications. London: Routledge.

Humphries, Stan. 2001. Who's afraid of the big, bad firm: The impact of economic scale on political participation. American Journal of Political Science 45 (3): 678-699.

Hunter, Albert, and Gerald D. Suttles. 1972. The expanding community of limited liability. In The social construction of communities, ed. Gerald D. Suttles, 44-81. Chicago: University of Chicago Press. 
Jones, Kelvyn. 1997. Multilevel approaches to modelling contextuality: From nuisance to substance in the analysis of voting behaviour. In Places and people: Multilevel modelling in geographical research, ed. G. P. Westert and R. N. Verhoeff, 19-43. Utrecht: The Royal Dutch Geographical Society.

Joye, Dominique, Thérèse Huissoud, and Martin Schuler. 1995. Habitants des quartiers, citoyens de la ville? Zürich: Seismo.

Kasarda, John D., and Morris Janowitz. 1974. Community attachment in mass society. American Sociological Review 39:328-339.

Krassa, Michael. 1995. Contextual conditioning of political information: Common themes from disparate data. In Spatial and contextual models of politics, ed. Munroe Eagles, 179-194. London: Taylor and Francis.

Kübler, Daniel. 2005. La métropole et le citoyen. Les agglomérations vues par leurs habitants. Lausanne: Presses polytechniques et universitaires romenades.

Ladner, Andreas, and Marc Bühlmann. 2007. Demokratie in den Gemeinden. Der Einfluss der Gemeindegrösse und anderer Faktoren auf die Qualität der lokalen Demokratie. Zürich: Rüegger.

Ladner, Andreas, Daniel Arn, Ueli Friedrich, Reto Steiner, and Jürg Wichtermann. 2000. Gemeindereformen zwischen Handlungsfähigkeit und Legitimation. Bern: Institut für Politikwissenschaft und Institut für Organisation und Personal.

Lee, Barrett A., R. S. Oropesa, Barbara J. Metch, and Avery M. Guest. 1984. Testing the decline-ofcommunity thesis: Neighborhood organizations in Seattle, 1929 and 1979. American Journal of Sociology 89 (5): 1161-1188.

Lindenfeld, Frank. 1964. Economic interest and political lnvolvement. The Public Opinion Quarterly 28 (1): 104-111.

Lipset, Seymour M., Paul Lazarsfeld, Allen H. Barton, and Juan Linz. 1954. The psychology of voting: An analysis of political behavior. In The handbook of social psychology, ed. Lindzey Gardner, 1124-1175. Cambridge: Addison-Wesley Company.

Lowndes, Vivien. 1995. Citizenship and urban politics. In Theories of urban politics, ed. David Judge, Gerry Stoker and Harold Wolman, 160-180. London: Sage.

Marshall, Thomas H. 1964. Class, citizenship and social development. Chicago: University of Chicago Press.

Meyer, Gil, Dominique Joye, and Michel Bassand. 1992. Vivre en métropole? Lausanne: IREC-DA/EPFL.

Mouritzen, Poul Erik. 1989. City size and citizens' satisfaction: Two competing theories revisited. European Journal of Political Research 17:661-688.

Nie, Norman H., G. Bingham Powell Jr., and Kenneth Prewitt. 1969. Social structure and political participation: Developmental relationships, II. American Political Science Review 63 (3): 808-832.

Oliver, Eric. 2000. City size and civic involvement in metropolitan America. American Political Science Review 94:361-373.

Paterson, Lindsay, and Harvey Goldstein. 1992. New statistical methods for analysing social structures: An introduction to multilevel models. British Educational Research Journal 17:387-393.

Putnam, Robert D. 2000. Bowling alone. The collapse and revival of American community. New York: Simon \& Schuster.

Ringel, Norman B., and Jonathan C. Finkelstein. 1991. Differentiating neighborhood satisfaction and neighborhood attachment among urban residents. Basic and Applied Social Psychology 12:177-193.

Robinson, William S. 1950. Ecological correlations and the behavior of individuals. American Sociological Review 15:351-367. 
Sampson, Robert J. 1988. Local friendship ties and community attachment in mass society: A multilevel systemic model. American Sociological Review 53:766-779.

Schaff, Alvin H. 1952. The effect of commuting on participation in community organizations. American Sociological Review 17:215-220.

Schofer, Evan, and Marion Fourcade-Gourinchas. 2001. The structural contexts of civic engagement. Voluntary association membership in comparative perspective. American Sociological Review 66:806-828.

Schumacher, Ulrike. 2003. Lohn und Sinn. Individuelle Kombinationen von Erwerbsarbeit und freiwilligem Engagement. Opladen: Leske und Budrich.

Snijders, Tom, and Roel Bosker. 1999. Multilevel analysis. An introduction to basic and advanced multilevel modeling. London: Sage.

Steenbergen, Marco R., and Bradford S. Jones. 2002. Modelling multilevel data structures. American Journal of Political Science 46 (1): 218-237.

Stinner, William F., Mollie Van Loon, Seh-Woong Chang, and Yongchan Byun. 1990. Community size, individual social position and community attachment. Rural Sociology 55:494-521.

Stoker, Laura, and Jake Bowers. 2002. Designing multi-level studies: Sampling voters and electoral contexts. In The future of election studies, ed. Mark N. Franklin and Christopher Wlezien, 77-109. Amsterdam: Pergamon.

Strate, John M., Charles J. Parrish, Charles D. Elderund Coit Ford III. 1989. Live span civic development and voting participation. American Political Science Review 83 (2): 443-464.

Stutzer, Alois, and Bruno S. Frey. 2000. Stärkere Volksrechte-Zufriedenere Bürger: eine mikroökonometrische Untersuchung für die Schweiz. Schweizerische Zeitschrift für Politikwissenschaft 6 (3): 1-30.

Taylor, Ralph B., Stephen D. Gottfredson, and Sidney Brower. 1984. Neighborhood naming as an index of attachment to place. Population and Environment: Behavioral and Social Issues $7: 103-125$.

Teachman, Jay, and Kyle Crowder. 2002. Multilevel models in family research: Some conceptual and methodological issues. Journal of Marriage and Family 64 (2): 280-294.

Toennies, Ferdinand. [1887] 1991. Gemeinschaft und Gesellschaft. Grundbegriffe der reinen Soziologie. Darmstadt: Wissenschaftliche Buchgesellschaft.

Uslaner, Eric M. 2002. The moral foundations of trust. Cambridge: Cambridge University Press.

Verba, Sidney, and Norman Nie. 1972. Participation in America: Political democracy and social equality. New York: Harper and Row.

Wilson, Thomas C. 1986. Community population size and social heterogeneity: An empirical test. American Journal of Sociology 91 (5): 1154-1169.

Wimmer, Andreas, Dieter Karrer, Angela Stienen, and Rebekka Ehret. 2000. Schlussbericht für das Forschungsprojekt "Integration-Segregation. Interkulturelle Beziehungen in Basel, Bern und Zürich”. Zürich: NFP 39.

Wirth, Louis. 1938. Urbanism as a way of life. American Journal of Sociology 44:1-24.

Woolever, Cynthia. 1992. A contextual approach to neighborhood attachment. Urban Studies 29:99-116. 